\author{
Волкова С.Ф. \\ кандидат економічних наук, доцент \\ E-mail: svetlana_ict@mail.ru \\ Щербатова К.О. \\ магістрант \\ кафедра економіки промисловості \\ Одеська національна академія харчових технологій \\ вул. Канатна, 112, м. Одеса, Україна, 65039 \\ E-mail: sherbatova-a@mail.ru
}

\title{
РОЗВИТОК КОМБІКОРМОВОГО ВИРОБНИЦТВА ЯК ОСНОВА ЗАБЕЗПЕЧЕННЯ ПРОДОВОЛЬЧОЇ БЕЗПЕКИ УКРАЇНИ
}

У статті охарактеризовано сучасний стан, особливості та тенденції розвитку комбікормового виробництва України. Наведено причини, чинники та наслідки державного втручання в аграрний сектор. Виявлено, що комбікормова промисловість забезпечує продовольчу безпеку та продовольчу незалежність країни. Представлено обґрунтування перспектив розвитку виробництва комбікормів.

Ключові слова: комбікормове виробництво, продовольча безпека, аграрний комплекс, розвиток.

Постановка проблеми та їі зв'язок з важливими науковими і практичними завданнями. Комбікормова галузь характеризується великими масштабами виробництва і виготовляе значиму продукцію, яка відіграє провідну роль у розвитку промислового тваринництва України. Частка споживання м'яса й м'ясопродуктів у раціоні населення України складає 24-28\% [2], що підтверджує їх статус як основного продукту харчування. Тому розвиток комбікормового виробництва є дуже актуальним.

Аналіз останніх публікацій 3 проблеми. Актуальним питанням технології виробництва і використання кормів, їх класифікації за походженням, поживністю та значимістю, номенклатурі приділено значну увагу у багатьох фундаментальних працях А.О. Бабича, А.М. Венедиктова, Б.В. Сгорова, М.М. Карпуся, А.М. Никитина, М.Т. Ноздріна, И.В. Петрухина, Л.І. Подобєда, А.І. Свеженцова, М.Г. Таранова, А.Х Сабирова, В.Ю. Чумаченка та інших провідних вчених у сфері кормовиробництва та годівлі сільськогосподарських тварин та птиці.

Формулювання цілей дослідження. Метою дослідження $є$ вивчення сучасного стану комбікормового виробництва, факторів підвищення ефективності виробництва кормів, вивчення змін на ринку виробництва комбікормів, прогнозування розвитку комбікормового виробництва в сучасних умовах.

Виклад основних результатів та їх обгрунтування. Питання продовольчої безпеки завжди посідає провідне місце у загальній національній безпеці кожної країни, оскільки є обов'язковою умовою та передумовою соціальної та економічної стабільності держави. Продукти харчування є важливими та незамінними в життєдіяльності людини.
В міжнародних угодах визначення продовольчої безпеки має наступне трактування - "це такий стан економіки, при якому всім і кожному гарантується забезпечення доступу до продуктів харчування, питної води та іншим продуктам в якості, асортименті і обсягах, достатніх для фізичного і соціального розвитку особистості, забезпечення здоров'я і відтворення населення країни" [12].

В сучасних умовах соціально-економічного розвитку агропромислового комплексу України комбікормова промисловість посідає особливе місце. Виробництво комбікормів $є$ проміжною ланкою виробничого ланцюга: постачальник сировини (сільськогосподарські підприємства, фермерські господарства) переробник (комбікормові підприємства) - споживач (птахівничі і тваринницькі комплекси). Тому комбікормова промисловість є однією з основ забезпечення населення м'ясною продукцією [1].

Недооцінка значущості комбікормової промисловості і занепад всього агропромислового комплексу України 90-х років негативно вплинули на економічну ефективність функціонування комбікормової промисловості, відбулися руйнації потужностей галузі, зниження обсягів виробництва, переорієнтація на інші види діяльності, банкрутство та закриття більшості підприємств. Тому на сьогоднішній день особливо актуальними є дослідження і пошук шляхів підвищення економічної ефективності функціонування підприємств комбікормової промисловості. Зростає потреба у застосуванні комплексного підходу щодо формування нових мобільних невеликих та ефективних підприємств, що займаються виготовленням комбікормів.

Протягом останнього десятиріччя агропромисловий комплекс охопили кризові явища. Най- 
більш руйнівними вони були у тваринництві і галузях, що його забезпечують: кормовиробництві та у виробництві комбікормів. Комбікорми низької якості: зернові складові становлять у середньому понад 70\%, що значно вище за рекомендації стандартів ЄС. Через відсутність необхідних компонентів комбікорми не збалансовані за основними поживними і біологічноактивними речовинами. Комбікорми для птиці містять до 12-14\% протеїну при нормі 16-17\%, для свиней та ВРХ-11\% при нормі 15-17 відсотків. Недостатній технологічний рівень переробки: лише $20 \%$ продукції виготовляється у вигляді гранул та комбікормової крупки. Через низьку платоспроможність вітчизняних споживачів реалізується лише $80 \%$ вироблених комбікормів, майже відсутній їх експорт. Розвиток комбікормової галузі $є$ невід'ємною умовою піднесення вітчизняного тваринництва до рівня конкурентоспроможності економічно розвинених країн.

Підвищення ефективності виробництва $\epsilon$ економічним наслідком процесу безперервного удосконалення факторів виробництва, джерелом якого можуть бути як інтенсивні, так і екстенсивні фактори процесу відтворення. Виходячи з того, що поєднання і взаємозв язок основних складових, резервів, напрямів та чинників підвищення ефективності розвитку комбікормової промисловості можна вважати шляхами іiі зростання, відмітимо, що приріст кінцевих результатів виробництва має досягатися за рахунок збільшення основних його факторів та підвищення їх віддачі.

Ринок комбікормів суттєво змінився: за останнім часом з'явилося багато нових компаній. Жорстка конкуренція на ринку робить позитивний вплив. Основний стимулюючий фактор на сьогодні «ціна-якість». До 2016 року ми будемо мати 9 млн. т комбікорму (30\% приріст), з поділом: $70 \%$ - вертикально-інтегровані агрохолдинги і $30 \%$ - інші господарства [3].

Прогнозується зростання обсягів виробництва сільськогосподарської продукції, однак змінюється і політика м'ясного виробництва. Найбільший відсоток по зростанню обсягів виробництва припадає на країни, що розвиваються, до цього сегменту відноситься і Україна.

Таким чином, поряд 3 високим потенціалом для України спостерігаються великі перспективи в розвитку.

На нашу думку, для якнайшвидшого розвитку комбікормової промисловості України потрібен розвиток вертикально-інтегрованих структур, а також створення нових модульних мобільних комбікормових виробництв, які забезпечать мінімальні витрати на виробництво комбікормів та розширення тваринницьких комплексів, швидке виведення 3 кризи виробництва комбікормів.

Для вирішення цього завдання необхідно розробити стратегію розвитку галузі, виділити пріоритетні напрямки, ключові проблеми, вирішення яких життєво важливо для розвитку пріоритетних напрямків, розробити шляхи вирішення цих проблем в умовах економіки, зруйнованої війною і жорсткого дефіциту фінансових ресурсів.
Щодо розвитку комбікормової промисловості в сучасних умовах, то найважливіше завдання розвитку галузі полягає у відновленні й удосконаленні виробничо-господарських зв'язків і економічних відносин як 3 постачальниками зерна i виробничих відходів при переробці сільськогосподарської продукції, так і зі споживачами комбікормів. На новий рівень має бути піднята економічна інтегрованість всіх учасників виробничого ланцюжка, взаємна їх зацікавленість в цілях створення умов для мультиплікативного впливу на збільшення випуску кінцевої продукції. Саме на вирішення цього завдання має бути в першу чергу націлена економічна стратегія розвитку комбікормової промисловості будь-якого регіону агропромислового комплексу України.

На думку експертів, зростання виробництва кормів буде адекватне зростанню потреб тваринництва. А їх недолік поки так і буде покриватися імпортом кормових компонентів [4].

У сучасних умовах кормовиробникам необхідно знаходити будь-які форми інтеграції з тваринницькими комплексами. Це пояснюється тим, що масова частка споживаних в країні комбікормів припадає на сільськогосподарські комплекси. Годування комбікормами є для них економічно вигідним.

Говорячи про перспективи вітчизняного кормового виробництва, варто зауважити, що багато в чому галузь залежить від державної підтримки: ефективного дотування, ефективних ставок кредитування та страхування ризиків у тваринництві.

Розробка стратегії розвитку підприємств повинна спиратися на економічну оцінку виробничої діяльності господарюючих суб'єктів. В умовах все зростаючого дефіциту ресурсів (особливо енергетичних), та неймовірного збільшення їх вартості, необхідно враховувати і ефект від вивільнення ресурсів. Крім того, для формування сприятливого співвідношення вартості з ціною реалізації в якості головного оцінного критерію доцільно використовувати рівень ризику за оцінкою беззбиткового обсягу продажів.

Господарчий механізм підприємств повинен розвиватися безперервно, плавно і без стрибкоподібних змін. Основи стратегії ефективного функціонування підприємств повинні становити [5; 6]:

- регулювання вартості комбікормів шляхом підбору інгредієнтів;

- виробництво комбікормів різних і за якістю, і за вартістю за рахунок розробки рецептури та різних обсягів виробництва;

- розширення сфери сервісного обслуговування товаровиробників і споживачів комбікормів, включаючи організацію консалтингової діяльності.

Безпеку продуктів харчування гарантує дотримання технологічного регламенту на кожному етапі виробництва, контроль якості сировини та готової продукції, рівень кваліфікації персоналу і багато інших важливих факторів.

Проте однією 3 найважливіших умов $є$ законодавча база, яка, на жаль, в нашій країні не відповідає сучасним тенденціям. Діючі державні стандарти на комбікорми суттєво обмежують розвиток асортименту комбікормової продукції, призводять до зни- 
ження ії конкурентоспроможності [7]. Причина полягає в тому, що державні стандарти передбачають граничні обмеження мінімального і максимального рівня обмінної енергії, змісту основних поживних і біологічно активних речовин у відповідності з різними видами тварин і птиці [8].

Проблема виробництва якісної, екологічно чистої продукції комбікормовою промисловістю набуває гостроти й актуальності в зв`язку 3 тим, що значна частина країни знаходиться під впливом наслідків чорнобильської аварії. Також останнім часом постала проблема неконтрольованого використання різноманітних добрив та фумігантів, котрі не пройшли атестації та реєстрації в органах санепідемстанції. Таким чином, важливим науковим і практичним завданням $є$ недопущення перевищення норм концентрації радіонуклідів та фумігантів в зерновій сировині.

Мобілізація і використання значних наявних резервів підвищення ефективності і розвитку комбікормової промисловості, як підтверджують всебічні аналітичні розрахунки, дають змогу забезпечити збільшення виробництва високоякісних і дешевих основних видів продовольства у 2,5-3 рази, що дало б змогу сформувати необхідний фонд продуктів харчуван- ня для подальшого задоволення потреб внутрішнього ринку та створити їх потужний експортний потенціал [10].

Сьогодні комбікормова промисловість України має можливість виробляти високоякісну продукцію, яка відповідала б вимогам сучасної зарубіжної селекції. Проте негативні фактори стримують розвиток галузі. Шляхом вирішення цієї проблеми є розробка, прийняття і введення Закону України «Про корми», який повинен стати основою для подальшого розвитку нормативно-технічної бази та комбікормової промисловості, даний закон відкриє необмежені горизонти виробництва високорентабельної продукції птахівництва та тваринництва. Також планування та прийняття програми «Розвиток виробництва комбікормів в Україні на 2015-2016 роки» стане новим поштовхом до розвитку галузі.

Забезпеченість високоякісними комбікормами багато в чому визначає рівень розвитку та економіку цього напрямку, так як в структурі собівартості тваринницької продукції вартість кормів досягає 6575\%. Тому комбікормова галузь є важливою ланкою в розвитку агропромислового комплексу країни [9]. У таблиці 1 наведені чинники та наслідки впливу державного втручання в аграрний сектор економіки України.

Таблиця 1

Чинники та наслідки впливу державного втручання в аграрний сектор [11]

\begin{tabular}{|l|l|}
\hline \multicolumn{1}{|c|}{ Чинники } & \multicolumn{1}{|c|}{ Наслідки впливу } \\
\hline Природно-кліматичні & $\begin{array}{l}\text { Неконтрольований вплив природно-кліматичних фак- } \\
\text { торів на сільськогосподарське виробництво вимагає } \\
\text { створення й розвиток системи страхування, що регу- } \\
\text { люється державою }\end{array}$ \\
\hline Нестійкість цін на сільськогосподарську продукцію & $\begin{array}{l}\text { Коливання цін відповідно до ринкової кон'юнктури } \\
\text { обумовлює нестабільність доходів у сільському гос- } \\
\text { подарстві. }\end{array}$ \\
\hline $\begin{array}{l}\text { Низький рівень концентрації сільськогосподарського } \\
\text { виробництва }\end{array}$ & $\begin{array}{l}\text { Низький рівень концентрації сільськогосподарського } \\
\text { виробництва зумовлює необхідність його підтримки і } \\
\text { захисту інтересів товаровиробників від високо моно- } \\
\text { полізованих галузей промисловості. }\end{array}$ \\
\hline
\end{tabular}

Висновки і перспективи подальших досліджень. Основна ідея стратегії національної продовольчої безпеки полягає в економічній відповідальності за якість продуктів харчування. Основою продовольчої безпеки $\epsilon$ формування таких економічних механізмів, які б забезпечили сталий розвиток агропромислового комплексу як в економічному, так і в екологічному сенсі. Це обумовлено підвищенням вимог стандартів до якості та безпеки продуктів харчування. Досягнення зазначеного базується в першу чергу на виробництві екологічно безпечної сировини рослинного походження та промисловому виробництві інгредієнтів кормового призначення.

Сучасний стан розвитку комбікормової промисловості потребує переходу на більш високий рівень виробництва, значного розширення асортименту і поліпшення якості продукції. Широке застосування повинні знайти і нові технологічні процеси, спрямовані на поглиблену переробку сировини при виробництві кормів на модульних мобільних установках.

\section{Література}

1. Кудренко Н. В. «Шляхи підвищення економічної ефективності функціонування підприємств комбікормової промисловості : авторефер. дис. ... канд. екон. наук : 08.00.04 / Н. В. Кудренко, Нац. ун-т харч. технологій. - К., 2013. - 21 с.

2. Григоренко О. «Формування харчових раціонів населення» / О. Григоренко // Товари і ринки, 2010. - № 2. - C. 118-124. 
3. Ринок комбікормової продукції. Україна. 2009-2013 рік [Електронний ресурс]. - Режим доступу: www. marketing. vc/ view_notes. php.

4. Рынок комбикормов. Украина. [Электронный ресурс]. - Режим доступа: www. marketing-vc. com. ua/.

5. Рынок комбикормов: положительная динамика в 2014 г. сохранится [Електронний ресурс]. - Режим доступа: www. farkom. com. ua/ /info/news/17.

6. Соловйов Б. А. Маркетинг. / Б. А. Соловйов, А. А. Мєшков, Б. В. Мусатов. - М. : Инфра-М, 2012.

7. Александрова М. В. Моделирование и анализ рынка комбикормов / М. В. Александрова, Л. Т. Печеная, А. А. Блюмин // Комбикорма. - 2000. - № 3. - С. 24-29.

8. Сорока К. О. Місце та роль маркетингових досліджень на підприємствах малого бізнесу / К. О. Сорока., А. А. Макаренко, Я. С. Стовба // Економіка, фінанси, право. - 2007. - № 6. - С. 7-11.

9. Біленький О. Ю. Невизначеність середовища у стратегії розвитку комбікормової промисловості [Текст] / О. Ю. Біленький // Маркетинг на міжнародних ринках товарів та послуг: глобальні аспекти : II міжнар. наук. -практ. конф. - Україна-Словаччина, 2011. - С. 20-23.

10. Шмаглій О. Б. Харчова промисловість та їі розвиток // Економіка АПК. - 2006. - № 8. - С. 45-46.

11. Ілляшенко С. М. Маркетингові дослідження : Навч. посіб. для студ. вищ. навч. закл. / С. М. Ілляшенко, М. Ю. Баскакова. Сумський держ. ун-т. - К. : Центр навчальної літератури, 2006. - 192 с.

12. Гойчук О.І. Продовольча безпека : Монографія. / О. І. Гойчук. - Житомир : Полісся, 2004. - 348 с.

Стаття надійшла 09.03.2015

\author{
Волкова С.Ф. \\ кандидат экономических наук, доцент \\ E-mail: svetlana_ict@mail.ru \\ Щербатова E.A. \\ магистрант \\ кафедра экономики промышленности \\ Одесская национальная академия пищевых технологий \\ ул. Канатная, 112, г. Одесса, Украина, 65039 \\ E-mail: sherbatova-a@mail.ru
}

\title{
РАЗВИТИЕ КОМБИКОРМОВОГО ПРОИЗВОДСТВА КАК ОСНОВА ОБЕСПЕЧЕНИЯ ПРОДОВОЛЬСТВЕННОЙ БЕЗОПАСНОСТИ УКРАИНЫ
}

В статье охарактеризовано современное состояние, особенности и тенденции развития комбикормового производства Украины. Приведены причины, факторы и последствия государственного вмешательства в аграрный сектор. Выявлено, что комбикормовая промышленность обеспечивает продовольственную безопасность и продовольственную независимость страны. Представлено обоснование перспектив развития производства комбикормов.

Определено, что в современных условиях социально-экономического развития агропромышленного комплекса Украины комбикормовая промышленность занимает особое место. Проанализирован рынок комбикормов, он существенно изменился: в последнее время появилось много новых компаний. Определили, что на новый уровень должна быть поднята экономическая интеграция всех участников производственной цепочки, взаимная их заинтересованность в целях создания условий для мультипликативного влияния на увеличение выпуска конечной продукции. Именно на решение этой задачи должна быть в первую очередь нацелена экономическая стратегия развития комбикормовой промышленности любого региона агропромышленного комплекса Украины.

Разработка стратегии развития предприятий должна опираться на экономическую оценку производственной деятельности хозяйствующих субъектов. В условиях все возрастающего дефицита ресурсов (особенно энергетических) и значительного увеличения их стоимости, необходимо учитывать и эффект от высвобождения ресурсов. Кроме того, для формирования благоприятного соотношения стоимости с ценой реализации в качестве главного оценочного критерия целесообразно использовать уровень риска по оценке безубыточного объема продаж. Хозяйственный механизм предприятий должен развиваться непрерывно, плавно и без скачкообразных изменений. Безопасность продуктов питания гарантируют соблюдение технологического регламента на каждом этапе производства, контроль качества сырья и готовой продукции, уровень квалификации персонала и многие другие важные факторы.

Проблема производства качественной, экологически чистой продукции комбикормовой промышленностью приобретает остроту и актуальность в связи с тем, что значительная часть страны находится под влиянием последствий Чернобыльской аварии.

Ключевые слова: комбикормовое производство, продовольственная безопасность, аграрный комплекс, развитие. 


\author{
Volkova S. F. \\ Ph.D., Associate Professor \\ E-mail: svetlana_ict@mail.ru \\ Sherbatova K.O. \\ Undergraduate \\ Department of Industrial Economics \\ Odessa National Academy of Food Technologies \\ Kanatna str., 112, Odessa, Ukraine, 65039 \\ E-mail: sherbatova-a@mail.ru
}

\title{
THE DEVELOPMENT OF MIXED FODDER PRODUCTION AS A BASIS FOR FOOD SECURITY IN UKRAINE
}

The paper characterized the current state, characteristics and trends of development of fodder production in Ukraine. The reasons of the factors and consequences of government intervention in the agricultural sector. It was revealed that the feed mill industry provides food security and food sovereignty of the country. Presented study the development prospects of production of animal feed.

It was determined that in the present conditions of socio-economic development of the agroindustrial complex of Ukraine feed mill industry has a special place. Analyze the market of feed, it has changed considerably in recent years, many new companies. We determined that a new level should be raised economic integration of all participants of the production chain, their mutual interest in order to create conditions for a multiplicative effect on the increase in the output of the final product. It is the solution of this problem must be primarily focused economic development strategy for the feed industry, any region of the agro-industrial complex of Ukraine.

Development of an enterprise development strategy should be based on an economic assessment of production activity of economic entities. In the context of the increasing scarcity of resources (especially energy) and a significant increase in their cost, it is necessary to take into account the effect of releasing resources. In addition to a favorable ratio of cost to the selling price in the quality of the main evaluation criteria should be used to assess the risk of break-even sales. The economic mechanism of the enterprises should develop continuously, smoothly and without abrupt changes. Food safety guarantee observance of production schedules at each stage of production and quality control of raw materials and finished products, the level of staff and many other important factors.

The problem of the production of high-quality, environmentally friendly products feed industry takes on urgency and relevance in view of the fact that a large part of the country is affected by the Chernobyl accident.

Keywords: feed milling, food security, agrarian complex, development.

\section{References}

1. Kudrenko N.V. (2013). «Shliakhy pidvyshchennia ekonomichnoi efektyvnosti funktsionuvannia pidpryiemstv kombikormovoi promyslovosti : avtorefer. dys. ... kand. ekon. nauk : 08.00 .04 / N. V. Kudrenko, Nats. un-t kharch. tekhnolohii. K., 21.

2. Hryhorenko O. (2010). Formuvannia kharchovykh ratsioniv naselennia. Tovary i rynky, № 2, 118124.

3. Rynok kombikormovoi produktsii. Ukraina. 2009-2013 rik. [Elektronnyi resurs]. Rezhym dostupu: www. marketing. vc/ view_notes. php.

4. Rynok kombikormov. Ukrayna. [Elektronnyi resurs]. Rezhym dostupa: www. marketing-vc. com. ua/.

5. Rynok kombikormov: polozhytelnaia dynamyka v 2014 h. sokhranytsia [Elektronnyi resurs]. Rezhym dostupa: www. farkom. com. ua/ /info/news/17.

6. Soloviov B.A., Mieshkov A.A., Musatov B.V. (2012). Marketynh. M.: Ynfra-M.

7. Aleksandrova M.V., Pechenaia L.T.,. Bliumyn A.A. (2000). Modelyrovanye i analyz rynka kombikormov. Kombykorma, № 3, 24-29.

8. Soroka K.O., Makarenko A.A., Stovba Ya.S. (2007). Mistse ta rol marketynhovykh doslidzhen na pidpryiemstvakh maloho biznesu . Ekonomika, finansy, pravo, № 6, 7-11.

9. Bilenkyi O.Yu. (2011). Nevyznachenist seredovyshcha u stratehii rozvytku kombikormovoi promyslovosti [Tekst]. Marketynh na mizhnarodnykh rynkakh tovariv ta posluh: hlobalni aspekty : II mizhnar. nauk. prakt. konf. Ukraina-Slovachchyna, 20-23.

10. Shmahlii O.B. (2006). Kharchova promyslovist ta yii rozvytok. Ekonomika APK, № 8, 45-46.

11. Illiashenko S.M., Baskakova M.Yu. (2006). Marketynhovi doslidzhennia: Navch. posib. dlia stud. vyshch. navch. zakl. Sumskyi derzh. un-t. K.: Tsentr navchalnoi literatury, 192.

12. Hoichuk O.I. (2004). Prodovolcha bezpeka: Monohrafiia. Zhytomyr: Polissia, 348. 